\title{
Zasada alteri stipulari nemo potest w prawie rzymskim
}

I. Prawo rzymskie stanowi, obok filozofii greckiej i chrześcijaństwa, fundament cywilizacji europejskiej', a zwłaszcza fundament europejskiej nauki prawa, podstawę nowożytnej dogmatyki cywilistycznej oraz międzynarodowy środek porozumienia prawników ${ }^{2}$. Nie oznacza to jednak, że dorobek wielowiekowej ewolucji prawa, zwłaszcza epoki wielkich kodyfikacji prawa cywilnego, ogranicza się do „przekucia” instytucji, konstrukcji dogmatycznych i zasad prawa rzymskiego na język współczesnych przepisów prawa. Przeciwnie, da się wskazać wiele zasad prawa antycznego, które w toku tej ewolucji przerodziły się $\mathrm{w}$ zasady stanowiące ich przeciwieństwo. Jedną z nich zawiera sentencja przywoływana przez żyjącego w III w. n.e. Domitiusa Ulpiana alteri stipulari nemo potest ${ }^{3}$. To krótkie sformułowanie okazuje się dość trudne do precyzyjnego przetłumaczenia na język polski, albowiem proponowane są jego następujące przekłady: „nikt nie może przyrzec spełnienia świadczenia dla kogoś innego jak wierzyciel”", „nikt nie może odebrać przyrzeczenia stypulacyjnego za inną osobę", ,nikt nie może przyjmować przyrzeczenia stypulacyjnego dla

${ }^{1}$ P. Koschaker: Europa und das römische Recht. München-Berlin 1953, s. 2; H. Kupiszewski: Prawo rzymskie i współczesność. Warszawa 1988, s. 16.

${ }^{2}$ M. Kuryłowicz: Prawo rzymskie. Historia - tradycja - współczesność. Lublin 2003, s. 23.

${ }^{3}$ Zob. źródła zamieszczone w tytule Digestów De verborum obligationibus (D.45.1).

${ }^{4}$ W. Bojarski, W. Dajczak, A. Sokala: Verba iuris. Reguły i kazusy prawa rzymskiego. Toruń 2007, s. 21.

5 Tłumaczenie za Digesta Iustiniani. Digesta Justyniańskie. Tekst i przekład. T. VII.1. Księgi 45-47. Red. T. Palmirski. Kraków 2017, s. 25 (D.45.1.38.17). 
drugiego"6, „nikt nie może zawrzeć stypulacji w zastępstwie drugiego"7, „nikt nie może stypulować w imieniu innej osoby”, ,nikt nie może zobowiązywać się za kogoś innego"9. Już na pierwszy rzut oka można dostrzec, że pomiędzy tymi tłumaczeniami występują dość subtelne różnice, w zależności od tego, który z poniżej opisanych aspektów tej złożonej zasady został podkreślony przez tłumacza. Tożsamą zasadę przywołał w II w. n.e. Gaius, stwierdzając w Instytucjach praeterea inutilis est stipulatio, si ei dari stipulemur, cuius subiecti non sumus $^{10}$ (,ponadto bezskuteczna jest stypulacja, jeśli odbieramy przyrzeczenie, że coś będzie dane temu, którego władzy nie podlegamy"), a nadto wynika ona z innych źródeł zawierających podobne semantycznie sformułowania ${ }^{11}$. Została ona utrzymana $\mathrm{w}$ prawie justyniańskim, czego najważniejszym dowodem jest zawarte w Instytucjach Justyniana stwierdzenie si quis alii, quam cuius iuri subiectus sit, stipuletur, nihil agit ${ }^{12}$ (,jeżeli ktoś odbiera przyrzeczenie dla innego niż ten, którego władzy podlega, niczego nie dokonuje").

II. Zasada alteri stipulari nemo potest odnosi się do trzech bardzo istotnych dla obrotu prawnego współcześnie dogmatycznie i normatywnie odróżnianych instytucji prawnych, właściwej (uprawniającej) umowy na rzecz osoby trzeciej, niewłaściwej (upoważniającej) umowy na rzecz osoby trzeciej i zastępstwa bezpośredniego (przedstawicielstwa). Na podstawie właściwej umowy na rzecz osoby trzeciej osoba niebędąca jej stroną ma prawo we własnym imieniu żądać świadczenia od dłużnika, w tym realizować to prawo na drodze sądowej. Niewłaściwa umowa na rzecz osoby trzeciej przewiduje natomiast, że dłużnik spełni świadczenie osobie trzeciej, jednakże nie kreuje dla tej osoby żadnych roszczeń bezpośrednio w stosunku do dłużnika, upoważniając ją jedynie do odbioru świadczenia na rachunek wierzyciela i pozostając przez to wiążąca tylko pomiędzy stronami. W pierwszym przypadku osoba trzecia nabywa swoje samodzielne roszczenie w stosunku do dłużnika na podstawie umowy, której nie jest stroną, $w$ drugim zaś jest jedynie odbiorcą świadczenia, które, $\mathrm{z}$ jednej strony, dłużnik spełnia, wykonując swoje zobowiązanie wobec wierzyciela,

${ }^{6}$ K. Kolańczyk: Prawo rzymskie. Warszawa 1997, s. 374.

${ }^{7}$ W. Wołodkiewicz w: Prawo rzymskie. Stownik encyklopedyczny. Red. W. Wołodkiewicz. Warszawa 1986, s.v. nemo alteri stipulari potest.

8 W. Dajczak w: W. Dajczak, T. Giaro, F. Longchamps de Bérier: Prawo rzymskie. U podstaw prawa prywatnego. Warszawa 2009, s. 503.

${ }_{9}$ M. Kuryłowicz: Stownik terminów, zwrotów i sentencji prawniczych łacińskich oraz pochodzenia łacińskiego. Kraków 2002, s. 100.

${ }^{10}$ Instytucje Gaiusa [dalej: G] G.3.103.

${ }_{11}$ Zob. D.44.7.11 (Paul. 12 ad Sab.) i następujące fragmenty Kodeksu Justyniana (C.): C.5.12.19 (Diocl. et Max., a. 294), C.8.38.3pr. (Diocl. et Max., a. 290).

${ }_{12}$ Zob. Instytucje Justyniana (I.) fragmenty I.3.19.4 i I.3.19.19. Cytaty, o ile nie zaznaczono inaczej, tłum. - M.S. 
a z drugiej — ten wierzyciel spełnia wobec niej jako jej dłużnik w ramach odrębnego stosunku prawnego łączącego go $\mathrm{z}$ nią ${ }^{13}$.

Analizując źródła prawa rzymskiego, należy jednak pamiętać, że konstrukcje dogmatyczne umów na rzecz osoby trzeciej i zastępstwa bezpośredniego stanowią dorobek nowożytnej nauki prawa i jako takie nie były znane prawu rzymskiemu. Zwłaszcza dopiero w czasach nowożytnych teoretycznie odróżniono umowy na rzecz osoby trzeciej od zastępstwa bezpośredniego ${ }^{14}$, co przesądziło zarazem o ostatecznej akceptacji instytucji zastępstwa bezpośredniego ${ }^{15}$. Stąd też w źródłach prawa rzymskiego nie można doszukiwać się rozróżnień, które dla współczesnego prawnika są już naturalne, co więcej, to samo źródło prawa rzymskiego w zależności od rozłożenia akcentów i sposobu jego interpretacji może być użyteczne w badaniach dotyczących korzeni zarówno umowy na rzecz osoby trzeciej, jak i zastępstwa bezpośredniego. Dość wspomnieć, że treść analizowanej paremii na pierwszy rzut oka wyraża zasadę niedopuszczalności zawarcia umowy na rzecz osoby trzeciej (zarówno umowy właściwej, jak i niewłaściwej), jednakże stanowi także argument, na rzecz tezy, że Rzymianie nie operowali ogólną konstrukcją zastępstwa bezpośredniego.

III. Cytowana sentencja zawarta jest we fragmencie 49. księgi komentarza Ulpiana do dzieł Sabinusa poświęconym kontraktowi stypulacji, umieszczonym przez kompilatorów justyniańskich w tytule czterdziestej piątej księgi Digestów De verborum obligationibus (D.45.1.38.17). Fragment ten zawiera najistotniejsze informacje dotyczące wyrażonej w niej zasady:

Alteri stipulari nemo potest, praeterquam si servus domino, filius patri stipuletur: inventae sunt enim huiusmodi obligationes ad hoc, ut unusquisque sibi adquirat

${ }^{13} \mathrm{Na}$ temat rozumienia umów na rzecz osoby trzeciej zob. H. Kötz, A. Flessner: European Contract Law. Vol. 1: Formation, Validity, and Content of Contracts, Contract and Third Parties. Oxford 1997, s. 245 i nast.; R. Morek w: Kodeks cywilny. Komentarz. Red. K. Osajda. Warszawa 2018, uwagi 8-10 do art. 393; P. Machnikowski w: Kodeks cywilny. Komentarz. Red. E. Gniewek. Warszawa 2018, uwaga 7 do art. 393.

${ }^{14}$ Rozróżnienie to podkreślił H. Grocjusz: O prawie wojny i pokoju. Paryż 1625, 2.11.18.

15 Proces ten przebiegał stopniowo przez setki lat, duży wkład wniosły tu ustawa kastylijskiego króla Alfonsa XI z 1348 r. (ley „Paresciendo”) i holenderska elegancka jurysprudencja, a ostatecznie zakończyła niemiecka pandektystyka. Pierwszą regulację prawną umowy na rzecz osoby trzeciej zawierało szwajcarskie prawo zobowiązań z $1881 \mathrm{r}$. Tematyce tej poświęcona jest praca zbiorowa pt. Contract For a Third-Party Beneficiary: A Historical and Comparative Account. Eds. J. Hallebeek, H. Dondorp. Leiden-Boston 2008, passim, poza tym zob. H. Koing: Europäisches Privatrecht. Bd. 1: Älteres Gemeines Recht (1500-1800). München 1985, s. 400; R. Zimmermann: The Law of Obligations. Roman Foundations of the Civilian Tradition. Cape Town-Wetton-Johannesburg 1990, s. 42 i nast.; H. Dondorp, J. Hallebeek: Grotius' Doctrine on "adquisitio obligationis per alterum" and its Roots in the Legal Past of Europe. In: Panta rei. Studi dedicati a Manlio Bellomo. Ed. O. Condorelli. Roma 2004, s. 205 i nast.; J. Hallebeek: Contract for a third party beneficiary: a brief sketch from the corpus iuris to present-day civil law. „Fundamina” 2007, issue 13.2, s. 11 i nast. 
quod sua interest: ceterum ut alii detur, nihil interest mea. plane si velim hoc facere, poenam stipulari conveniet, ut, si ita factum non sit, ut comprehensum est, committetur stipulatio etiam ei, cuius nihil interest: poenam enim cum stipulatur quis, non illud inspicitur, quid intersit, sed quae sit quantitas quaeque condicio stipulationis.

Nikt nie może odebrać przyrzeczenia stypulacyjnego za inną osobę, za wyjątkiem sytuacji, gdy niewolnik przyjmuje przyrzeczenie za właściciela, a syn pozostający pod władzą za ojca rodziny. Zobowiązania tego rodzaju zostały wymyślone po to, aby każdy bez wyjątku nabywał dla siebie to, na czym mu zależy. Nie jest zresztą $\mathrm{w}$ moim interesie, by coś było dane komuś innemu. W każdym razie, jeśli chciałbym do tego doprowadzić, stosowana jest ku temu stypulacja kary umownej, po to, by, jeśli nie stanie się to, co stanowi przedmiot stypulacji, wywołała ona skutki także wobec tego, którego nie dotyczy. Jeżeli bowiem ktoś przyrzeknie karę umowną, to nie jest rozważane, co stanowi interes prawny, ale jaki jest zakres i treść stypulacji16.

Ulpian wskazuje zatem na zasadę alteri stipulari nemo potest, podając jej uzasadnienie i trzy najistotniejsze wyjątki od niej, tj. stypulację przyjętą przez niewolnika lub osobę podległą władzy ojcowskiej, istnienie własnego interesu osoby przyjmującej przyrzeczenie, aby świadczenie zostało spełnione osobie trzeciej i zastrzeżenie kary umownej.

Analiza tych aspektów wymaga poczynienia kilku uwag na temat rzymskiej stypulacji.

$\boldsymbol{I} \boldsymbol{V}$. Stipulatio była kontraktem werbalnym, wymagającym zachowania pewnych wymogów formalnych ${ }^{17}$, z których najistotniejszy odnosił się do sposobu, $\mathrm{w}$ jakim strony składały sobie oświadczenia woli. Mianowicie w okresie prawa klasycznego wierzyciel (stipulator) ustnie pytał dłużnika (promissor), „czy przyrzekasz" spełnić określone świadczenie, zaś dłużnik bezpośrednio odpowiadał „przyrzekam”, używając tego samego czasownika, który był zawarty w pytaniu ${ }^{18}$. Nie była więc to forma skomplikowana. Zakres zastosowania stypulacji był bardzo szeroki, albowiem mogła ona służyć kreacji zobowiązania o dowolnej treści, byleby tylko spełniającego podstawowe wymogi ważnej obligatio, na czele ze

16 Tłumaczenie za Digesta Iustiniani. Digesta Justyniańskie. Tekst i przekład. T. VII.1. Księgi 45-47. Red. T. Palmirski. Kraków 2017, s. 25 (D.45.1.38.17).

${ }_{17}$ Zob. definicję stipulatio podaną przez Pomponiusa w D. 45.1.5.1 (Pomp. 26 ad Sab.). Wymogi tego kontraktu szczegółowo roztrząsa Ulpian w 48 księdze komentarza do dzieł Sabinusa (D. 45.1.1-6).

${ }^{18}$ Zob. G.3.92-94, D.45.1.1-6 (Ulp. 48 ad Sab.), I.3.15.1. W praktyce obok ustnej wymiany pytania $\mathrm{i}$ odpowiedzi strony już $\mathrm{w}$ okresie republiki sporządzały dokument $\mathrm{w}$ celach dowodowych, a w prawie poklasycznym zasadnicze znaczenie przywiązywano do dokumentu. Istotną zmianę $\mathrm{w}$ formie stypulacji wprowadziła konstytucja cesarza wschodniorzymskiego Leona I z 472 r. (C. 8.37.10), dopuszczając możliwość użycia jakichkolwiek słów. 
zgodnością z prawem i dobrymi obyczajami ${ }^{19}$. W praktyce zatem $\mathrm{w}$ znacznym stopniu stipulatio wypełnia lukę spowodowaną obowiązywaniem w prawie rzymskim zasady nominalizmu kontraktowego, przeciwstawianej ukształtowanej poprzez wieki, choć ostatecznie dopiero w prawie nowożytnym, swobodzie umów $^{20}$. Znacząca rola kontraktu stypulacyjnego w antycznym Rzymie powodowała, że pewne zasady wypracowane na jego gruncie przenoszono na inne kontrakty i pacta, czego przykładem jest zasada alteri stipulari nemo potest. Jednym z najważniejszych dowodów na to jest stwierdzenie Quintusa Muciusa Scaevoli przejęte przez kompilatorów do tytułu Digestów zawierającego zasady prawa nec paciscendo nec legem dicendo nec stipulando quisquam alteri cavere potest $^{21}$ (,nikt nie może zabezpieczyć drugiemu korzyści poprzez zawarcie nieformalnej umowy, dodanie do głównego aktu prawnego jednostronnej klauzuli, zwykle o charakterze ograniczającym czy stypulację zawartą z osobą trzecią"22). Zasięg stosowania tej zasady nie ograniczał się zatem do kontraktu stypulacji, lecz obejmował wszystkie kontrakty i pacta ${ }^{23}$.

$\boldsymbol{V}$. Analizowana sentencja wyraża zasadę, że w rzymskim kontrakcie stypulacji i wszystkich pozostałych kontraktach nie było możliwe skuteczne zastrzeżenie świadczenia na rzecz osoby trzeciej, tj. osoby niebędącej stroną kontraktu, lecz wyłącznie na rzecz osoby przyjmującej przyrzeczenie, $\mathrm{tj}$. wierzyciela stypulacyjnego (stipulator) ${ }^{24}$. Nie oznacza to, co prawda, że w prawie rzymskim obowiązywał formalny zakaz zawierania kontraktu stypulacji na rzecz osoby trzeciej, lecz jedynie tyle, że zawarta w ten sposób stypulacja nie wywoływała

19 Stypulacja mogła odnosić się do świadczeń nieobjętych innymi kontraktami, poza tym była wykorzystywana m.in. do zastrzeżenia kary umownej (stipulatio poenae), odsetek towarzyszących udzieleniu pożyczki, ustanowienia poręczenia, odnowienia (novatio), zmiany strony zobowiązania, ustanowienia posagu, zaciągnięcia zobowiązania gwarancyjnego (cautio). Mogła także mieć za przedmiot świadczenia właściwe dla innych kontraktów, np. zwrot pożyczki, zapłatę ceny sprzedaży, wzmacniając pozycję wierzyciela. Zob. W. Wołodkiewicz w: Wielka encyklopedia prawa. T. 1: Prawa świata antycznego. Red. B. Sitek, W. Wołodkiewicz. Warszawa 2014, s.v. stipulatio; D. Zybała w: Leksykon tradycji prawa prywatnego. Pojęcia podstawowe. Red. A. Dębiński, M. Jońca. Warszawa 2016, s.v. stipulatio.

${ }^{20} \mathrm{Na}$ temat rzymskiego nominalizmu kontraktowego i ewolucji w kierunku zasady swobody umów opublikowałem ostatnio pracę pt. Condictio causa data causa non secuta and development of the contractual system. „Krakowskie Studia z Historii Państwa i Prawa” 2018, T. 11, z. 2, s. $177-195$.

${ }^{21}$ D. 50.17.73.4 (Muc. 1.S.horwn).

${ }^{22}$ Tłumaczenie za Digesta Iustiniani, Digesta Justyniańskie. Tekst i przekład. T. VII.2. Księgi 48-50. Red. T. Palmirski. Kraków 2017, s. 419.

${ }^{23}$ Por. J. Hallebeek: Contract..., s. 12; S. Pilloni: La posizione del terzo nel diritto delle obbligazioni, 2014, s. 98 i nast., https://iris.unipa.it/retrieve/handle/10447/109068/153805/ La posizione del terzo nel diritto delle obbligazioni. Tesi di Dottorato Dott.ssa Sara Pilloni.pdf [dostęp: 1.03.2019].

${ }^{24}$ J. Hallebeek: Roman law. In: Contract For a Third-Party Beneficiary: A Historical and Comparative Account. Eds. J. Hallebeek, H. Dondorp. Leiden-Boston 2008, s. 8 i nast.; J. Hallebeek: Contract..., s. 12. 
skutków prawnych, także pomiędzy jej stronami ${ }^{25}$. Odnosi się to przy tym zarówno do umowy, w której osoba trzecia miałaby uzyskać własne samodzielne roszczenie w stosunku do dłużnika (umowa uprawniająca), jak i takiej, w której zostałaby jedynie upoważniona do przyjęcia świadczenia (umowa upoważniająca). Ponadto sentencja ta stanowi dowód na to, że Rzymianie nie uznawali możliwości składania i przyjmowania oświadczenia woli w cudzym imieniu i na cudzą rzecz, zatem osoba przyjmująca przyrzeczenie nie mogła być zastępcą bezpośrednim innej osoby, która miałaby stać się wierzycielem stypulacyjnym ${ }^{26}$. W konsekwencji zasada ta jest wyrazem niechęci jurystów rzymskich do ujmowania osoby trzeciej w strukturze zobowiązania, czego dalszym przykładem był zwłaszcza brak w pełni ukształtowanej cesji wierzytelności ${ }^{27}$. Rzymianie postrzegali zobowiązanie (obligatio) jako węzeł prawny (vinculum iuris) ${ }^{28}$ o charakterze osobistym, łączący dłużnika z wierzycielem, co do zasady bez możliwości uwzględnienia $\mathrm{w}$ nim osoby trzeciej $\mathrm{w}$ jakiejkolwiek roli ${ }^{29}$. To wyobrażenie sięga korzeniami najdawniejszego prawa rzymskiego, w którym osoba dłużnika stanowiła gwarancję wykonania zaciągniętego przez niego zobowiązania, dłużnik bowiem osobiście poddawał się władzy wierzyciela, zaś ów węzeł (vinculum) był rozumiany dosłownie - jako węzeł krępujący dłużnika poddanego egzekucji per manus iniectionem ${ }^{30}$.

$\boldsymbol{V I}$. Powstaje pytanie, czym motywowana była analizowana zasada. Ulpian podaje, że jej uzasadnieniem jest brak zasługującego na ochronę prawną interesu osoby przyjmującej przyrzeczenie ${ }^{31}$, aby świadczenie zostało spełnione innej osobie i podkreśla, że ,zobowiązania tego rodzaju zostały wymyślone po to, by każdy bez wyjątku nabywał dla siebie to, na czym mu zależy”. Tożsame

${ }^{25}$ Potwierdzeniem tego jest fakt, że w Instytucjach Justyniana regulacji prawnej tej problematyki nadano tytuł De inutilibus stipulationibus (I.3.19), por. Idem: Roman law..., s. 9; Idem: Contract..., s. 12; S. Pilloni: La posizione..., s. 98 i nast.

${ }^{26}$ Aczkolwiek jeszcze dobitniejszy argument przeciwko przedstawicielstwu stanowi zasada nemo alieno nomine lege agere potest (nikt nie może działać w imieniu innej osoby) zawarta D.50.17.123pr. (Ulp. 14 ad ed.).

${ }^{27}$ Prawu rzymskiemu była jednak znana możliwość zabezpieczenia wierzytelności przez osobę trzecią poprzez poręczenie (adpromissio).

${ }^{28}$ I.3.13.pr.

${ }^{29}$ Zob. D.44.7.11 (Paul. 12 ad Sab.), por. B. Schlösser: Die Bedeutung der praepositio für den Handelsverkehr im antiken Rom. Berlin 2008, s. 16. Szerokie omówienie rzymskiej koncepcji obligatio z przywołaniem wcześniejszej literatury zawiera dysertacja S. Pilloni: La posizione..., s. 18 i nast.

${ }^{30}$ Był to tryb egzekucji, którego przedmiotem była osoba dłużnika, a nie jego majątek. $\mathrm{W}$ toku postępowania egzekucyjnego dłużnik taki mógł być więziony przez wierzyciela, krępowany kajdanami a nawet sprzedany. Szczegółowy opis tego trybu zawierała ustawa XII tablic z połowy V. w. p.n.e. (Tablica 3 ).

${ }^{31} \mathrm{~W}$ epoce radykalnej krytyki źródeł wzmiankę o interesie uważano za interpolację, zob. G. Wesenberg: Verträge zugunsten Dritten. Rechtsgeschichtliches und Rechtsvergleichendes. Weimar 1949, s. 11 i nast. 
uzasadnienie podane jest w Instytucjach Justyniana ${ }^{32}$. Słowa te powinno się odczytywać po części jako uzasadnienie obowiązywania samej zasady i po części jako uzasadnienie funkcjonujących w praktyce i poświadczonych źródłowo dopuszczalnych wyjątków od niej.

Korzeni tej zasady i zarazem przyczyn jej powstania upatruje się w oprócz zarysowanym już wyobrażeniu zobowiązania jako węzła prawnego łączącego strony, w sformalizowanym charakterze rzymskiej stipulatio i w ogóle najstarszych czynności prawnych (nexum, sponsio, mancipatio) ${ }^{33}$ oraz w zasadach rzymskiego procesu cywilnego $\mathrm{w}$ dobie procesu legisakcyjnego i formułkowego.

Jeżeli chodzi o sam kontrakt stypulacji, to treść pytania zadawanego dłużnikowi przez wierzyciela co najmniej w początkach rozwoju tego kontraktu zawierała zaimek mihi (,,czy przyrzekasz mi...”), co uniemożliwiało przyrzeczenie świadczenia na rzecz osoby trzeciej34. Nawet stopniowe ,poluzowywanie” formalizmu słownego tego kontraktu i rezygnacja z konieczności użycia zaimka mihi nie zmieniły zasady, że świadczenie było przyrzekane jedynie osobie odbierającej przyrzeczenie stypulacyjne. Tym bardziej starsze od stypulacji najdawniejsze czynności prawne $\mathrm{w}$ archaicznym prawie rzymskim, takie jak sponsio, nexum, mancipatio ze względu na swój formalistyczny charakter i wymóg osobistego uczestnictwa stron w procesie ich zawierania uniemożliwiały włączenie osoby trzeciej w strukturę zobowiązania jako uprawnionej do żądania świadczenia, a zapewne nawet nie brano pod uwagę, aby osoba uczestnicząca w tej czynności czyniła to w cudzym imieniu i interesie ${ }^{35}$.

Ostatnio w badaniach romanistycznych obok powyższego uzasadnienia uwzględnia się także aspekt procesowy, formułując tezę, że prawdopodobnie to właśnie zasady procesu formułkowego, zasadniczej formy procesu w okresie prawa klasycznego, uzasadniały obowiązywanie zasady alteri stipulari, a przynajmniej przesądziły o jej dalszym stosowaniu mimo przeobrażeń istoty zobowiązania, stopniowego zmniejszania rygoryzmu słownego stypulacji i rozkwitu odformalizowanych czynności prawnych, na czele z kontraktami konsensualnymi. $\mathrm{W}$ prawie klasycznym na przeszkodzie skutecznemu zastrzeganiu świadczenia na rzecz osoby trzeciej mogły stać ówcześnie obowiązujące zasady procesu formułkowego, w tym przede wszystkim treść formułki procesowej i zasada, że zasądzenie mogło nastąpić jedynie w pieniądzu (kondemnacja pieniężna), i to także wtedy, kiedy odbiorca przyrzeczenia stypulacyjnego miał jakiś własny interes $\mathrm{w}$ spełnieniu świadczenia osobie trzeciej ${ }^{36}$. W przypadku świadczeń po-

32 I.3.19.19.

33 R. Zimmermann: The Law.., s. 35; S. Pilloni: La posizione..., s. 99 i nast.; R. van der Bergh: He's One Who Minds the Boss's Business. „Fundamina” 2015, issue 21/2, s. 359 i nast.

${ }_{34}$ G. Wesenberg: Verträge..., s. 11 i nast.; R. Zimmermann: The Law..., s. 35.

35 H. Kötz, A. Flessner: European Contract..., s. 218.

${ }^{36}$ H. Ankum: Une nouvelle hypothèse sur l'origine de la règle alteri dari stipulari nemo potest. In: Études offertes à Jean Macqueron. Aix-en-Provence 1970, s. 21-29, R. Zimmermann: The Law..., s. 37 i nast.; J. Hallebeek: Roman law..., s. 10. 
legających na dare ${ }^{37}$ przeszkodę stanowiła treść formułki chroniącej stypulację skargi procesowej nazywanej condictio, zawierającej jako wymóg zasądzenia konieczność ustalenia, że pozwany miał spełnić (dare) określone świadczenie powodowi ${ }^{38}$, a nie zatem osobie trzeciej. Gdyby więc wierzyciel stypulacyjny działał $\mathrm{w}$ charakterze powoda, to nie mógłby spełnić tej przesłanki, albowiem świadczenie stosownie do zawartego kontraktu należało spełnić nie jemu, lecz innej osobie. Ewentualny własny interes powoda w zastrzeżeniu świadczenia na rzecz osoby trzeciej, nawet wymierny majątkowo i dający się oszacować, niczego by tu nie zmienił, formułka procesowa nadal uniemożliwiałaby zapewnienie skuteczności takiej stypulacji ${ }^{39}$. Podobne ograniczenie treścią formułki procesowej nie zachodziło jednak w przypadku świadczeń polegających na facere $^{40}$, gdyż w takim przypadku treść formułki actio ex stipulatu ${ }^{41}$ umożliwiała sędziemu oszacowanie interesu powoda w tym, aby osoba trzecia otrzymała świadcze$n e^{42}$. Treść formułki procesowej nie stała tu zatem na przeszkodzie, a wymóg kondemnacji pieniężnej mógł zostać zachowany. Stąd też wyciąga się wniosek, że w prawie klasycznym obowiązywała zasada alteri stipulari dari nemo potest (nikt nie może odebrać przyrzeczenia, że coś zostanie dane osobie trzeciej) ${ }^{43}$, jednakże możliwe było skuteczne zastrzeganie świadczeń polegających na facere, choć jedynie w tym zakresie, w jakim zachodził prawnie chroniony wymierny, tj. dający się oszacować, interes majątkowy wierzyciela stypulacyjnego, aby takie świadczenie zostało spełnione ${ }^{44}$. Opisane ograniczenia procesowe na czele z treścią formułki procesowej i zasadą kondemnacji pieniężnej odpadły w kolejnej fazie rozwoju rzymskiego procesu prywatnego nazywanej procesem kognicyjnym (cognitio extra ordinem). Możliwe stało się zatem zastrzeganie świadczeń polegających zarówno na dare, jak i na facere, skuteczne pod warunkiem wykazania własnego interesu prawnego osoby przyjmującej przyrzeczenie ${ }^{45}$.

VII. Zachowane źródła zawierają przykłady własnego wymiernego finansowo interesu osoby przyjmującej przyrzeczenie w spełnieniu świadczenia osobie trzeciej. I tak np. ten $\mathrm{z}$ dwóch opiekunów, który powierzył wyłączne

${ }^{37}$ Dare (dać) to przeniesienie własności rzeczy lub ustanowienie ograniczonego prawa rzeczowego, zob. M. Jońca w: Leksykon..., s.v. dare.

38 Si paret Numerium Negidium Aulo Agedio decem dare oportere.

${ }^{39}$ R. Zimmermann: The Law..., s. 36; J. Hallebeek: Roman law..., s. 10.

${ }^{40}$ Facere (czynić) odnosi się do innych świadczeń niż polegających na przeniesieniu własności rzeczy lub ustanowieniu ograniczonego prawa rzeczowego, zob. M. Jońca w: Leksykon..., s.v. dare.

${ }^{41}$ Quod Aulus Agerius de Numerio Negidio incertum stipulates est, quidquid ob eam rem Numerium Negidium facere oportet, eius iudex Numerium Negidium Aulo Agerio condemnato, si non paret, absolvito.

42 J. Hallebeek: Roman law..., s. 11.

${ }^{43}$ Zasadę tę zawierają: G.3.103, C.8.38(39).3 (Diocl. et Max., a. 290).

${ }^{44}$ R. Zimmermann: The Law..., s. 36; J. Hallebeek: Roman law..., s. 11.

45 J. Hallebeek: Roman law..., s. 12 i nast. 
sprawowanie opieki współopiekunowi, mógł od niego żądać zabezpieczenia nazywanego cautio rem pupilli salvam fore, że majątek osoby niedojrzałej podlegającej opiece będzie nietknięty ${ }^{46}$. Własny interes opiekuna polegał tu na tym, że w dalszym ciągu odpowiadał wobec pupila za sprawowanie opieki, w tym za czynności dotychczasowego współopiekuna, któremu powierzył wyłączne sprawowanie opieki ${ }^{47}$.

Podobnie własny interes osoby przyjmującej przyrzeczenie zachodził wtedy, kiedy dłużnik przyrzekał świadczenie jej wierzycielowi, albowiem interes ten polegał na tym, aby w ten sposób zostało wykonane zobowiązanie tej osoby wobec jej wierzyciela, co pozwoliłoby jej uniknąć negatywnych skutków odpowiedzialności kontraktowej, egzekucji majątkowej, zapłaty kary pieniężnej (umownej) lub sprzedaży zastawionych gruntów ${ }^{48}$. Szczególnym przykładem takiej sytuacji jest zobowiązanie do wykonania dzieła, na przykład budowy kamienicy, na rzecz osoby, której wykonanie takiego dzieła przyrzekł odbiorca przyrzeczenia ${ }^{49}$. W takim przypadku odbiorca przyrzeczenia, który zamierza wykonać swoje zobowiązanie wobec osoby trzeciej z pomocą przyrzekającego (podwykonawcy) ma interes prawny, aby dzieło to zostało wykonane.

Następnym ważnym wyjątkiem od zasady bezskuteczności stipulatio alteri była możliwość zastrzeżenia kary pieniężnej (stipulatio poenae) na wypadek, gdyby dłużnik nie spełnił świadczenia osobie trzeciej. W takim przypadku samo zastrzeżenie kary pieniężnej jest skuteczne, bez względu na ewentualny towarzyszący jej inny interes osoby przyjmującej przyrzeczenie, aby świadczenie zostało spełnione na rzecz osoby trzeciej. Wystarczający jest bowiem sam fakt zastrzeżenia zapłaty określonej kwoty tytułem kary umownej ${ }^{50}$, zaś zasady procesu formułkowego nie stały na przeszkodzie zasądzeniu takiej kary.

Poza przykładami wzmiankowanymi w cytowanym źródle także w kontrakcie zlecenia (mandatum), zleceniobiorca mógł zobowiązać się spełnić świadczenie będące jego przedmiotem, choćby dokonać zapłaty, do rąk osoby trzeciej, a nie zleceniodawcy (mandatum alteri) ${ }^{51}$. Prawo rzymskie znało również delegatio solvendi odpowiadającą współczesnemu przekazowi, w której to wierzyciel (delegans) polecał swojemu dłużnikowi (delegatus) spełnić świadczenie osobie trzeciej (delegatarius) ${ }^{52}$. Sam zaś kontrakt stypulacji dopuszczał możliwość

46 Przykład ten jest przywoływany przez Ulpiana cytującego Marcellusa (D. 45.1.38.20, Ulp. 49 ad Sab.) i w Instytucjach Justyniana (I. 3.19.20).

${ }^{47}$ G. Wesenberg: Verträge..., s. 12 i nast.

${ }^{48}$ D.45.1.38.23 (Ulp. 49 ad Sab.); I.3.19.20.

${ }^{49}$ D.45.1.38.21 (Ulp. 49 ad Sab.). Z fragmentu tego wynika, że zobowiązanie do wykonania dzieła mogło być przedmiotem zarówno stypulacji, jak i kontraktu najmu dzieła (locatio conductio operis faciendi).

${ }^{50}$ D.45.1.38.23 (Ulp. 49 ad Sab.); D.45.1.118.2 (Pap. 27 quaest.), I.3.19.19.

${ }^{51}$ I.3.26.3.

${ }^{52}$ Zob. zwłaszcza D.12.1.32 (Cels. 5 dig.), D.12.4.9 pr. (Paul. 17 ad Plaut.), D.23.3.78.5 (Tryph. 11 disp.), D.39.6.18.1 (Iul. 60 dig.), D.39.6.31.3 (Gai. 8 ad ed. prov.), D.46.3.38.1 (Afric.). 
uprawnienia innej osoby jako wierzyciela ubocznego (adstipulator) do odbioru przyrzeczonego świadczenia, lecz to uprawnienie stanowiło jedynie pochodną praw osoby przyjmującej przyrzeczenie jako wierzyciela głównego ${ }^{53}$. Podobną funkcję pełnił solutionis causa adiectus ${ }^{54}$.

Należy zauważyć jednak, że we wzmiankowanych przez Ulpiana przypadkach to sam odbiorca przyrzeczenia stypulacyjnego mający własny interes w jego wykonaniu na rzecz osoby trzeciej lub zastrzegający karę pieniężną mógł żądać naprawienia szkody wynikającej z jego niewykonania lub nienależytego wykonania albo zapłaty kary pieniężnej. Osoba trzecia natomiast nie uzyskiwała samodzielnego roszczenia o wykonanie zobowiązania lub odszkodowawczego za jego niewykonanie albo o zapłatę kary pieniężnej ${ }^{55}$. Podobnie $\mathrm{w}$ przypadku mandatum alteri to nie osoba trzecia, lecz zleceniodawca mógł żądać, aby to świadczenie zostało spełnione osobie trzeciej, ale tylko gdy sam miał w tym wymierny majątkowo interes ${ }^{56}$. Tym samym ze współczesnej perspektywy taki kontrakt nie stanowił właściwej umowy na rzecz osoby trzeciej, lecz jedynie umowę niewłaściwą.

$\boldsymbol{V I I I}$. Niemniej w źródłach zachowały się dalej idące przykłady wyjątków od zasady alteri stipulari nemo potest, albowiem uprawniające osobę trzecią do żądania świadczenia. Jednym $\mathrm{z}$ nich było towarzyszące darowiźnie uzgodnienie, że obdarowany po upływie określonego czasu przekaże przedmiot darowizny osobie trzeciej ${ }^{57}$, co mieściło się $\mathrm{w}$ zakresie darowizny z poleceniem (donatio sub modo). W tym przypadku uprawniona osoba trzecia mogła żądać wydania jej przedmiotu darowizny ${ }^{58}$. Wierzyciel zastawny, zawierając umowę sprzedaży przedmiotu zastawu, mógł uzgodnić z kupującym, że jeżeli dłużnik zapłaci kupującemu kwotę równą cenie, zastawiona rzecz zostanie mu zwrócona ${ }^{59}$. Dłużnik w takim przypadku mógł bezpośrednio żądać wydania mu rzeczy od kupującego za pomocą rei vindicatio lub actio in factum ${ }^{60}$. Ojciec, który ustanawiał posag córce, mógł przyjąć przyrzeczenie od odbiorcy posagu, że ten zwróci go określonej osobie, zwłaszcza córce lub jej spadkobiercom ${ }^{61}$. Uprawniony do żądania

53 G.3.110.

54 D.24.3.45 (Paul. 6 quaest.), D.45.1.56.2 (Iul. 2 dig.), D.46.3.10 (Paul. 4 ad Sab.).

55 Por. H. Kötz, A. Flessner: European Contract..., s. 246 i nast.; J. Hallebeek: Roman law..., s. 9; Idem: Contract..., s. 12.

56 Por. J. Hallebeek: Roman law..., s. 16.

57 C.8.54.(55).3 (Diocl. et Max., a. 290), FV. 286.

58 Osobie tej przysługiwała actio utilis z uwagi na przychylną interpretację prawa, zob. C.8.54(55).3.1 (Diocl. et Max., a. 290).

59 D.13.7.13.pr. (Ulp. 38 ad ed.).

${ }^{60} \mathrm{~W}$ najnowszej literaturze nadal podtrzymywany jest pogląd, że jest to rozwiązanie obce prawu klasycznemu, a wzmianka o tych skargach stanowi interpolację, zob. S. Pilloni: La posizione..., s. 126 i nast.

${ }^{61}$ D.23.4.9 (Pomp. 16 ad Sab.), D.24.3.45 (Paul. 6 quaest.), C.5.12.26 (Diocl.), C.5.14.4 (Gord., a. 239), C.5.14.7 (Diocl. et Max., a. 294). 
zwrotu posagu mógł skorzystać z actio utilis ${ }^{62}$. Wydzierżawiający grunt, który zawierał umowę jego sprzedaży, mógł uzgodnić z kupującym, że ten uszanuje stosunek dzierżawny ${ }^{63}$. Osoba, która oddawała cudzą rzecz w użyczenie lub na przechowanie, mogła ustalić z biorącym tę rzecz w użyczenie lub depozytariuszem, że ten odda rzecz jej właścicielowi ${ }^{64}$. W takim przypadku właścicielowi przysługiwała actio utilis depositi o wydanie mu przedmiotu depozytu ${ }^{65}$. Przykłady te potwierdzają zatem, że osoba trzecia mogła żądać świadczenia przysługującego jej na podstawie kontraktu, którego nie była stroną, co odpowiada współczesnej właściwej umowie na rzecz osoby trzeciej. Były to jednak nieliczne wyjątki od zasady, a nie zasada, podyktowane szczególnym charakterem relacji łączących strony umowy i osobę trzecią oraz względami słuszności ${ }^{66}$.

$\boldsymbol{I} \boldsymbol{X}$. Na szersze odniesienie zasługuje pierwszy z cytowanych przez Ulpiana wyjątków od zasady alteri stipulari nemo potest, mianowicie dopuszczalne było przyjęcie stypulacji przez niewolnika na rzecz jego pana (dominus) oraz przez syna rodziny (filius familias) podległego władzy ojcowskiej (patria potestas) na rzecz jego pater familias. Uprawnionym z tytułu takiej stypulacji stawał się zwierzchnik osoby przyjmującej przyrzeczenie. Wyjątek ten szeroko analizował w II w. n.e. Gaius w swych Instytucjach (G.2.95):

Ex his apparet per liberos homines, quos neque iuri nostro subiectos habemus neque bona fide possidemus, item per alienos servos, in quibus neque usumfructum habemus neque iustam possessionem, nulla ex causa nobis adquiri posse. et hoc est, quod vulgo dicitur per extraneam personam nobis adquiri non posse; tantum de possessione quaeritur, an per liberam personam nobis adquiratur.

$\mathrm{Z}$ tego wynika, że za pośrednictwem osób wolnych, których nie mamy pod naszą władzą ani w posiadaniu w dobrej wierze, ani za pośrednictwem cudzych niewolników, których nie mamy ani w użytkowaniu, ani w posiadaniu zgodnym $\mathrm{z}$ prawem, nie możemy nabyć dla nas niczego z jakiegokolwiek tytułu. To jest to, o czym pospolicie się mówi, że przez osoby postronne nabycie dla nas nie jest możliwe. Jedynie co do posiadania zadaje się pytanie, czy może być dla nas nabyte przez osobę wolną ${ }^{67}$.

Z cytowanego fragmentu wynika, że zasadą było osobiste działanie osób nabywających prawa, zwłaszcza osobiste dokonywanie czynności prawnych

${ }^{62}$ Możliwość ta wzmiankowana jest w D.24.3.45 (Paul. 6 quaest.) i C.5.14.7 (Diocl. et Max., a. 294).

${ }_{63}^{63}$ D.19.2.25.1 (Gai. 10 ad ed. provinc.).

${ }^{64}$ C.3.42.8 (Diocl. et Max., a. 293), por. Collatio 10.7.8.

${ }^{65}$ C.3.42.8 (Diocl. et Max., a. 293).

${ }^{66}$ Por. S. Pilloni: La posizione..., s. 202 i nast.

${ }^{67}$ Gai Institutiones. Instytucje Gaiusa. Z języka łacińskiego przełożył, wstępem i uwagami opatrzył W. Rozwadowski. Poznań 2003, s. 57. 
przysparzających, bez możliwości posłużenia się osobą trzecią. Reprezentantem rzymskiej familia i właścicielem jej majątku był jej zwierzchnik nazywany pater familias. Wyjątkiem od tej zasady było nabycie prawa przez zwierzchnika za pośrednictwem osób jemu podległych, tj. nie tylko własnych niewolników i dzieci podlegających władzy ojcowskiej, ale także cudzych niewolników wziętych w użytkowanie lub posiadanych w dobrej wierze ${ }^{68}$. Z samych Instytucji Gaiusa wynika, że kategoria tych osób była nieco szersza, albowiem obejmowała także osoby oddane w zależność osobistą nazywaną mancipium, osoby wolne błędnie uważane za niewolników i żonę w małżeństwie cum $\operatorname{manu}^{69}$. To samo rozwiązanie utrzymano $\mathrm{w}$ prawie poklasycznym ${ }^{70} \mathrm{i}$ justyniańskim ${ }^{71}$. Osoby te mimo braku zdolności prawnej (niewolnicy) lub jej ograniczenia (dzieci in potestate) $)^{72}$ posiadały zdolność do czynności prawnych, mogły więc zawierać umowy ze skutkiem dla zwierzchnika w zakresie uzyskanych przysporzeń majątkowych. W antycznym świecie oznaczało to szeroką możliwość nabywania praw z umów zawartych nie osobiście, lecz poprzez czynności prawne innych osób. Ten jurydyczny wyjątek w praktyce był na tyle szeroki, że nie odczuwano palącej potrzeby odrzucenia samej zasady i dopuszczenia jako reguły możliwości posłużenia się osobą trzecią wolną i zarazem niepodlegającą władzy. Niewątpliwie rozwiązanie to było podyktowane wymogami obrotu, albowiem w warunkach intensywnego rozwoju gospodarki i stosunków handlowych patres familias, zwłaszcza w bogatych rodzinach przedsiębiorców, nie mogli wszystkich operacji przeprowadzać osobiście ${ }^{73}$.

Zawarte w przywoływanym źródle stwierdzenie per extraneam personam nobis adquiri non potest (przez osoby postronne nabycie dla nas nie jest możliwe) zawiera podobną myśl co zasada alteri stipulari nemo potest, jednakże odnosi się przede wszystkim do możliwości nabycia praw za pośrednictwem innej osoby jako swego rodzaju przedstawiciela. Czynność prawna zdziałana przez osobę podległą przynosi skutek w postaci nabycia prawa bezpośrednio przez jej zwierzchnika, zwierzchnik nie jest tu jedynie osobą trzecią, którą uprawnia się do żądania świadczenia lub upoważnia do jego odebrania. $Z$ tego względu ze współczesnego punktu widzenia zasada przywoływana przez Gaiusa dotyczy problemu zastępstwa bezpośredniego (przedstawicielstwa) przy czynnościach prawnych, nie zaś umów na rzecz osoby trzeciej ${ }^{74}$. Nie oznacza to jednak, że

${ }^{68}$ Wniosek ten znajduje potwierdzenie także w innych źródłach zob. np. G.2.86-96, D.45.1.38.6 (Ulp. 49 ad Sab.), I. 3.17.1.

${ }^{69}$ Zob. G.2.86-96.

${ }^{70}$ C.4.27.1 (Diocl. et Max., a. 290), PS.5.2.2.

${ }^{71}$ I. $2.9 .3-5$, I.3.17.1.

${ }_{72}$ Jak stwierdza Gaius qui in potestate nostra est, nihil suum habere potest (G.2.87).

${ }^{73}$ Przypuszcza się nawet, że w późnej republice i pryncypacie niewolnicy ogrywali pierwszoplanową rolę w obrocie handlowym, zob. W.W. Buckland: The Roman Law of Slavery. The Condition of the Slave in the Private Law from Augustus to Justinian. Cambridge 1908, s. 131.

${ }^{74}$ F.K. v. Savigny początku przedstawicielstwa dopatrywał się właśnie w możliwości nabywania posiadania i prawa za pośrednictwem osób podległych. Por. F.K. Savigny: Das 
przywoływane wyjątki stanowią dowód istnienia w prawie rzymskim konstrukcji odpowiadającej współczesnemu zastępstwu bezpośredniemu choć niekiedy osoby te określa się jako „organy" "75 zwierzchnika. Przeciwnie, możliwość nabycia prawa za pośrednictwem niewolnika lub osoby alieni iuris stanowi swoiste rozwiązanie prawa rzymskiego, do którego współcześnie nawiązuje się przy okazji analizy zastępstwa bezpośredniego głównie w tym aspekcie, że z uwagi na szeroką możliwość posłużenia się osobami podległymi nie powstała potrzeba kreacji odrębnej instytucji prawnej odpowiadającej współczesnemu zastępstwu bezpośredniemu ${ }^{76}$.

Dopuszczalność nabywania praw poprzez osoby in potestate wynikała ze struktury ówczesnego społeczeństwa i rodziny rzymskiej ${ }^{77}$. Podstawową różnicę $\mathrm{w}$ porównaniu ze współczesnym przedstawicielstwem stanowi przy tym fakt, że osoby te dokonywały czynności prawnych we własnym imieniu, a nie $\mathrm{w}$ imieniu zwierzchnika ${ }^{78}$. Działały one w sferze prawnej pater familias lub dominus, choć tylko w ograniczonym zakresie, i nie były do tego umocowane specjalnym pełnomocnictwem udzielonym przez niego do składania oświadczeń woli w jego imieniu i na jego rzecz. Takie umocowanie nie wynikało też z mocy prawa, albowiem prawo ograniczało się do przyjęcia, że to, co zostało nabyte wskutek czynności tych osób, było nabywane do majątku ich zwierzchnika. Nie miały one zdolności prawnej w ogóle (niewolnicy) lub też nie miały tzw. czynnej zdolności majątkowej (dzieci in potestate), dlatego wszystko, co nabywały, nabywały dla swego zwierzchnika.

Czynności zdziałane przez osoby podległe ponadto tym różnią się od czynności podejmowanych współcześnie przez przedstawiciela, że co do zasady wywoływały skutek prawny dla zwierzchnika jedynie w zakresie przysporzenia do jego majątku, natomiast nie w zakresie zobowiązania kosztem jego majątku. Obowiązywała bowiem zasada melior condicio nostra per servos fieri potest, deterior fieri non potest (nasza sytuacja prawna może stać się lepsza poprzez

Recht des Besitzes. Eine civilistische Abhandlung. Giessen 1837, s. 351 i nast. Podobny pogląd utrzymuje się także we współczesnej literaturze zob. Y. Wang: Actiones adiecticiae qualitatis. Responsabilità del pater familias per l'attività dei servi o fili o sottoposti. Roma 2009, passim.

75 Tak W. Litewski: Rzymskie prawo prywatne. Warszawa 1994, s. 156; K. Kolańczyk: Prawo..., s. 219.

${ }^{76}$ Zob. np. R. Zimmermann: The Law..., s. 48; J.D. Harke: Römisches Recht. München 2008, s. 75; R. Van der Bergh: He's..., s. 360 i nast. Podzielam w tym miejscu pogląd A.R. Jurewicz, że biorąc pod uwagę wysoki poziom rzymskiej nauki prawa, gdyby instytucja zastępstwa bezpośredniego była potrzebna, z pewnością zostałaby wypracowana lub recypowana $\mathrm{z}$ innego porządku prawnego i odpowiednio dostosowana do własnych potrzeb (A.R. Jurewicz: Pater familias dominusve iussit. Umowy na podstawie polecenia zwierzchnika. Olsztyn 2015, s. 313).

${ }_{77}$ W. Litewski: Rzymskie prawo..., s. 156; H. Kötz, A. Flessner: European Contract..., s. 228; R. Van der Bergh: He's..., s. 362.

${ }^{78}$ Por. A.R. Jurewicz: Pater..., s. 27. 
niewolników, ale nie może stać się gorsza) ${ }^{79}$. Zobowiązania zaciągnięte przez osoby podległe miały w prawie klasycznym co do zasady charakter zobowiązań naturalnych obciążających ich samych, niemożliwych do wyegzekwowania na drodze sądowej, jednakże jeżeli zostały wykonane, wywoływało to skutek w majątku zwierzchnika, albowiem świadczenie z nich wynikające nie stanowiło indebitum i nie podlegało zwrotowi. Osoba podległa związana zaciągniętym zobowiązaniem naturalnym zwykle posiadała faktyczną możliwość i wolę wykonania tego zobowiązania, zwykle też za wyraźną lub dorozumianą zgodą swego zwierzchnika. Mimo zatem niezaskarżalnego charakteru tych zobowiązań były one przeważnie wykonywane, w przeciwnym razie rozwiązanie to zostałoby odrzucone przez praktykę. Ważnym wyjątkiem w tym aspekcie były zobowiązania zaciągane przez syna podlegającego władzy ojcowskiej, albowiem miały one charakter zobowiązań zaskarżalnych, choć egzekucja była możliwa dopiero po ustaniu władzy ojcowskiej ${ }^{80}$.

Wymogi pewności obrotu spowodowały jednak, że stopniowo zwierzchnik stawał się odpowiedzialny za zobowiązania zaciągnięte przez osoby podległe. W praktyce pretorskiej okresu późnej republiki i wczesnego pryncypatu wypracowano bowiem skargi umożliwiające zasądzanie zwierzchnika w pewnych typowych sytuacjach. Skargom tym nadano w średniowieczu nazwę actiones adiecticiae qualitatis ${ }^{81}$. Zwierzchnik odpowiadał za zobowiązania zaciągnięte przez osoby podległe w przypadku udzielonego im upoważnienia (iussum) ${ }^{82}$, a w braku upoważnienia do wysokości wzbogacenia uzyskanego z ich czynności w chwili wyrokowania ${ }^{83}$, oraz w przypadku wydzielenia osobie podległej części

${ }^{79}$ D.50.17.133 (Gai. 8 ad ed. provinc.), por. G.3.104.

${ }^{80}$ D.15.1.44 (Ulp. 63 ad ed.).

${ }^{81}$ Nazwę tę nadali glosatorowie zainspirowani treścią fragmentu komentarza Paulusa do edyktu (D.14.1.5.1, Paul. 29 ad ed.), albowiem nowa actio została dodana (adicitur) do już istniejącej skargi ius civile. Literatura na temat tych skarg jest bardzo bogata, dlatego ograniczam się do przywołania prac ostatnio publikowanych, zawierających obszerną bibliografię, zob. M. Micelli: Studi sulla struttura formulare delle actiones adiecticiae qualitatis. Torino 2001 oraz Eadem: Studi sulla „rappresentanza” nel diritto romano. Milano 2008; M. Vandolini: Actiones adiecticiae qualitatis: categoria dogmatica o nomen iuris? Macerata 2008; Y. Wang: Actiones..., passim.

${ }^{82}$ Kontrahentowi przysługiwała w takim przypadku actio quod iussu. Skardze tej poświęcona jest wydana ostatnio obszerna monografia A.R. Jurewicz: Pater..., passim. Iussum jako upoważnienie do zawarcia kontraktu wykazuje pewne podobieństwo do współczesnego pełnomocnictwa, niekiedy nawet traktowane jest jako pierwowzór takowego (H. Kötz, A. Flessner: European Contract..., s. 218). Niemniej konstrukcyjnie iussum różniło się od pełnomocnictwa, zwłaszcza wszystkie opisane w niniejszym opracowaniu różnice pomiędzy działaniem za pośrednictwem osób podlegających władzy i przedstawicielstwem odnoszą się także do iussum. Zob. G.4.70, fragmenty zamieszczone w tytule D.15.4 oraz I.4.7.1, I.4.7.8.

${ }^{83}$ Roszczenie to, ograniczone wartością wzbogacenia uzyskanego przez zwierzchnika (np. wzbogacenia wynikającego ze świadczenia wzajemnego spełnionego przez kontrahenta lub z faktu, że z udzielonej przez niego pożyczki zostały zakupione jakieś rzeczy dla zwierzchni- 
majątku do zarządzania (peculium) $^{84}$. Ponadto, jeżeli osoba podległa została ustanowiona kierownikiem (institor) przedsiębiorstwa (zakładu handlowego) zwierzchnika lub kapitana jego statku (magister navis) zwierzchnik odpowiadał za całość (in solidum) ze stosunków umownych lub podobnych do nich w granicach dokonanego ustanowienia (praepositio) ${ }^{85}$.

$\boldsymbol{X}$. Wymaga podkreślenia jednak, że nawet w tych przypadkach, w których właściciel niewolnika lub pater familias ponosił odpowiedzialność za zobowiązania zaciągnięte przez osoby mu podległe, była to odpowiedzialność o charakterze dodatkowym, obok odpowiedzialności osób podległych jako stron kontraktu. Osoby te, legitymując się zdolnością do czynności prawnych, zaciągały swoje własne zobowiązania, choć, jak mowa o tym powyżej, mające charakter jedynie zobowiązań naturalnych (niewolnicy) lub też co prawda zaskarżalnych, ale możliwych do wyegzekwowania dopiero po ustaniu władzy ojcowskiej (filius familias). Nawet tutaj bowiem nie dopuszczono możliwości, aby osoby te działały ze skutkami wyłącznie dla ich zwierzchnika, w podobny sposób jak współczesny przedstawiciel czyni to, reprezentując zastępowanego ${ }^{86}$. Niemniej przyjęcie odpowiedzialności zwierzchnika o charakterze dodatkowym w stosunku do odpowiedzialności tych osób jako stron kontraktu, z jednej strony, chroniło ich kontrahentów, ale z drugiej strony — spowodowało, że stali się znacznie atrak-

ka), było realizowane poprzez actio de in rem verso. Zob. G.4.72a, tytuł D.15.3, I. 4.7.4-4b, I.4.7.8. Na temat tej skargi zob. w szczególności monografię T. Chiusi: Die actio de in rem verso im römischen Recht. München 2001 oraz ostatnio Y. Wang: Actiones..., s. 90 i nast.

${ }^{84}$ Służyła temu actio de peculio, zaś w przypadku gdy peculium służyło prowadzeniu działalności gospodarczej actio tributoria. Zob. G.4.72a-74, tytuły D.14.4 i D.15.1, I.4.7.3-4, I.4.7.5a. W przypadku actio de peculio wartość peculium wyznaczała granicę odpowiedzialności zwierzchnika (przy uwzględnieniu wzajemnych wierzytelności zwierzchnika i osoby zarządzającej peculium), choć egzekucja mogła być skierowana do całego jego majątku. Na temat actio de peculio zob. ostatnio E. Ejankowska: Zastosowanie actio de peculio z powodu filiae familias w okresie pryncypatu. „Zeszyty Naukowe Uniwersytetu Rzeszowskiego”, Seria Prawnicza 2016, z. 94, s. 23 i nast.; Y. Wang: Actiones..., s. 73 i nast. Actio tributoria stała się ostatnio przedmiotem zainteresowania A. Cassarino: El papel de la actio tributoria en el sistema de los procedimientos concursales romanos. „Rivista de Derecho - Universidad Católica der Norte" 2016, Vol. 23, s. 243 i nast., zob. także Y. Wang: Actiones..., s. 105 i nast.

${ }^{85}$ Służyły temu odpowiednio actio institoria i actio exercitoria. Zob. G.4.71, I.4.7.2-2a, tytuł D.14.1, a w odniesieniu do actio institoria tytuł D.14.3. Skargom tym poświęcona jest monografia J. Krzynówka: Odpowiedzialność przedsiębiorcy (exercitor) w prawie rzymskim. Warszawa 2000. Na temat actio institoria zob. ostatnio J.J. Aubert: Business Managers in Ancient Rome. A Social and Economic Study of Institores, 200 B.C. - A.D. 250. Leiden-New York-Köln 1994, passim; I. Żeber: Jeszcze o institorze $i$ o actio institoria.: „Acta Universitatis Wratislaviensis”. Prawo CCCX 2009, s. 29 i nast., Y. Wang: Actiones..., s. 44 i nast. O actio exercitoria zob. J. Krzynówek: Granice praepositio przy actio exercitoria. „Prawo Kanoniczne” 1994, nr 37, s. 175 i nast.; Y. Wang: Actiones..., s. 28 i nast.; M. Miskić: Actiones adiecticiae qualitatis: Master's liability based on praepositio and iussum. „Ius Romanum” 2017, No. 2, s. 1 i nast.

${ }^{86}$ H. Kötz, A. Flessner: European Contract..., s. 219. 
cyjniejsi jako uczestnicy obrotu i zarazem mogli być pełniej wykorzystywani przez zwierzchnika w prowadzonej przez niego działalności gospodarczej ${ }^{87}$. Ryzyko ich kontrahentów znacznie bowiem zmniejszyło się, skoro powstała bezpośrednia możliwość realizacji roszczeń w stosunku do zwierzchnika. Wprowadzenie wzmiankowanych skarg dodatkowych pozostawało zatem w interesie zarówno zwierzchnika, jak i samych kontrahentów osób jemu podległych.

$\boldsymbol{X I}$. Począwszy od prawa klasycznego, skargi dodatkowe były stosowane także wobec zobowiązań zaciągniętych za pośrednictwem osób wolnych niepodlegających władzy. Sam Gaius podaje w Instytucjach, że actio institoria i actio exercitoria miały zastosowanie także w sytuacji, w której kierownikiem przedsiębiorstwa lub kapitanem statku została ustanowiona osoba wolna, niepodlegająca władzy ich właściciela (extraneus) ${ }^{88}$. Papinian rozszerzył to rozwiązanie, proponując actio ad exemplum institoriae w odniesieniu do zobowiązań zaciągniętych przez zarządcę każdego majątku (procurator), będącego osobą wolną i niepodlegającą władzy właściciela tego majątku ${ }^{89}$. Począwszy od konstytucji cesarzy Honoriusza i Teodozjusza z 422 r..$^{90}$, iussum mogło zostać udzielone także wolnemu lub półwolnemu zarządcy cudzego gruntu ${ }^{91}$. Co prawda wszystkie te przykłady stanowiły krok w kierunku instytucji przedstawicielstwa, niemniej i w tych przypadkach extraneus nie stawał się przedstawicielem osoby, której interesy prowadził, albowiem także w odniesieniu do niego aktualne pozostawały opisane wyżej różnice pomiędzy charakterem działań i odpowiedzialnością osób podległych i współczesnym zastępstwem bezpośrednim ${ }^{92}$. Niemniej w odniesieniu do iussum w Instytucjach Justyniana przyznanie konkurencyjnej wobec actio quod iussu bezpośredniej skargi w stosunku do zwierzchnika (condictio), uzasadniano $\mathrm{w}$ ten sposób, że directo posse a patre dominowe condici tamquam si principaliter cum ipso negotium gestum esset ${ }^{93}$ (można żądać za pomocą

${ }^{87}$ J. Krzynówek: Odpowiedzialnośćc..., s. 15 i nast.; A.R. Jurewicz: Pater..., s. 19.

${ }^{88}$ G.4.71. Wprost na taką możliwość wskazuje też Ulpian w D.14.3.7.1 (Ulp. 28 ad ed.), dotyczy to zwłaszcza wyzwoleńca (D.14.3.20, Scaev. 5 dig.). Zob. także I.4.7.2a.

${ }^{89}$ D.14.3.19pr. (Pap. 3 resp.), D.19.1.13.25 (Ulp. 32 ad ed.). Szerzej na ten temat N. Benke: $\mathrm{Zu}$ Papinians actio ad exemplum institoriae. „Zeitschrift der Savigny-Stiftung für Rechtsgeschichte, Romanistiche Abteilung“ 1988, Nr. 105, s. 392 i nast.; T. Chiusi: Landwirtschafliche Tätigkeit und actio institoria. „Zeitschrift der Savigny-Stiftung für Rechtsgeschichte, Romanistiche Abteilung“ 1991, Nr. 108, s. 155 i nast.; A. Wacke: Von der Reeder- und der Betriebsklage zur direkten Stellvetretung. „Zeitschrift der Savigny-Stiftung für Rechtsgeschichte, Romanistiche Abteilung“ 1994, Nr. 111, s. 281; J. Krzynówek: Odpowiedzialność..., s. 118 i nast.; W. Simshäuser: Papinians Beitrag einer Rechtsscheinhaftung im klassischen römischen Recht. In: Studi in onore di Mario Talamanca. Napoli 2001, T. 7, s. 487; M. Micelli: Studi sulla „rappresentanza”..., s. 19 i nast.

${ }^{90}$ CTh. 2.31.1, przejęta z pewnymi zmianami w Kodeksie Justyniana (C.4.26.13).

${ }^{91} \mathrm{~W}$ konstytucji tej wymienia się jako zarządców gruntu coloni, procutores, actores i conductores. Szczegółowej jej analizy dokonała A.R. Jurewicz: Pater..., s. 293 i nast.

${ }_{92}$ J.D. Harke: Römisches Recht..., s. 78.

${ }^{93}$ I.4.7.8. 
condictio bezpośrednio od ojca lub właściciela, tak jak gdyby czynność została zdziałana głównie z nim samym). Stąd już blisko do współczesnego przedstawicielstwa.

XII. W cytowanym powyżej fragmencie Instytucji Gaius wskazuje na możliwość nabycia posiadania przez osobę wolną i zarazem niepodlegającą władzy osoby, dla której nabycie to następuje. Wyjątek ten odnosił się do zarządcy cudzego majątku (procurator), który mógł nabyć posiadanie rzeczy nawet bez wiedzy właściciela zarządzanego majątku. Posiadanie nabyte w ten sposób mogło prowadzić do równoczesnego nabycia własności wskutek samego wydania rzeczy, jeżeli osoba, która wydała rzecz, była jej właścicielem lub wskutek zasiedzenia, jeżeli osoba, która wydała rzecz, nie była jej właścicielem. Wyjątek ten prawdopodobnie wynikał z faktu, że często zarządcą majątku był wyzwoleniec, a zatem osoba, która jeszcze będąc niewolnikiem zajmowała się interesami swego pana. W Instytucjach Justyniana możliwość nabycia posiadania i własności $\mathrm{w}$ ten sposób odniesiona jest $\mathrm{w}$ ogólności do osób wolnych, a procurator jest wskazywany jedynie przykładowo ${ }^{94}$.

XIII. Przegląd źródeł dowodzi, że formalnie zasada alteri stipulari nemo potest obowiązywała przez cały okres antycznego prawa rzymskiego, począwszy od prawa archaicznego do justyniańskiego. Wyobrażenie o osobistym charakterze węzła obligacyjnego było tak silne, że zasada ta nie została nigdy uchylona. Dopuszczalność nabycia prawa poprzez osoby podległe zaspokajała w przeważającym stopniu istniejące potrzeby obrotu i czyniła zbyteczną próbę odrzucenia zasady. Niemniej zakres narastających w toku rozwoju prawa wyjątków od niej powodował, że pomimo jej formalnego obowiązywania prawo rzymskie znało, choć jedynie w bardzo ograniczonym stopniu, konstrukcje przypominające współczesną umowę na rzecz osoby trzeciej i instytucję zastępstwa bezpośredniego.

\section{Bibliografia}

An kum H.: Une nouvelle hypothèse sur l'origine de la règle alteri dari stipulari nemo potest. In: Études offertes à Jean Macqueron. Ed. P. Andrieu-Guitrancourt. Aix-en-Provence 1970.

Aubert J.J.: Business Managers in Ancient Rome. A Social and Economic Study of Institores, 200 B.C. - A.D. 250. Leiden-New York-Köln 1994.

Benke N.: Zu Papinians actio ad exemplum institoriae. „Zeitschrift der Savigny-Stiftung für Rechtsgeschichte, Romanistiche Abteilung“ 1988, Nr. 105.

${ }^{94}$ Rozwiązanie to utrzymało się w prawie justyniańskim, zob. I.2.9.5. 
Bojarski W., Dajczak W., Sokala A.: Verba iuris. Reguty i kazusy prawa rzymskiego. Toruń 2007.

Buckland W.W.: The Roman Law of Slavery. The Condition of the Slave in the Private Law from Augustus to Justinian. Cambridge 1908.

Cassarino A.: El papel de la actio tributoria en el sistema de los procedimientos concursales romanos. „Rivista de Derecho - Universidad Católica der Norte” 2016, T. 23.

Chiusi T.: Die actio de in rem verso im römischen Recht. München 2001.

Chiusi T.: Landwirtschafliche Tätigkeit und actio institoria. „Zeitschrift der Savigny-Stiftung für Rechtsgeschichte, Romanistiche Abteilung“" 1991, Nr. 108.

Contract For a Third-Party Beneficiary: A Historical and Comparative Account. Eds. J. Hallebeek, H. Dondorp. Leiden-Boston 2008.

Dajczak W., Giaro T., Longchamps de Bérier F.: Prawo rzymskie. U podstaw prawa prywatnego. Warszawa 2009.

Digesta Iustiniani. Digesta Justyniańskie. Tekst i przekład. T. VII.1. Księgi 45-47. Red. T. Palmirski. Kraków 2017.

Digesta Iustiniani, Digesta Justyniańskie. Tekst i przekład. T. VII.2. Księgi 48-50. Red. T. Palmirski. Kraków 2017.

Dondorp H., Hallebeek J.: Grotius' Doctrine on "adquisitio obligationis per alterum" and its Roots in the Legal Past of Europe. In: Panta rei. Studi dedicati a Manlio Bellomo. Ed. O. Condorelli. Roma 2004.

Ejankowska E.: Zastosowanie actio de peculio z powodu filiae familias $w$ okresie pryncypatu. „Zeszyty Naukowe Uniwersytetu Rzeszowskiego”, Seria Prawnicza 2016, z. 94.

Gai Institutiones. Instytucje Gaiusa. Z języka łacińskiego przełożył, wstępem i uwagami opatrzył W. Rozwadowski. Poznań 2003.

Hallebeek J.: Contract for a third party beneficiary: a brief sketch from the corpus iuris to present-day civil law. „Fundamina” 2007, z. 13/2.

Hallebeek J.: Roman law. In: Contract For a Third-Party Beneficiary: A Historical and Comparative Account. Eds. J. Hallebeek, H. Dondorp. Leiden-Boston 2008.

Harke J.D.: Römisches Recht. München 2008.

Jurewicz A.R.: Pater familias dominusve iussit. Umowy na podstawie polecenia zwierzchnika. Olsztyn 2015.

Kodeks cywilny. Komentarz. Red. E. Gniewek. Warszawa 2018.

Kodeks cywilny. Komentarz. Red. K. Osajda. Warszawa 2018.

Koing H.: Europäisches Privatrecht. Bd. 1: Älteres Gemeines Recht (1500-1800). München 1985.

Kolańczyk K.: Prawo rzymskie. Warszawa 1997.

Koschaker P.: Europa und das römische Recht. München-Berlin 1953.

Kötz H., Flessner A.: European Contract Law. Vol. 1: Formation, Validity, and Content of Contracts, Contract and Third Parties. Oxford 1997.

Krzynówek J.: Granice praepositio przy actio exercitoria. „Prawo Kanoniczne” 1994, nr 37.

Krzynówek J.: Odpowiedzialność przedsiębiorcy (exercitor) w prawie rzymskim. Warszawa 2000. 
Kupiszewski H.: Prawo rzymskie i współczesność. Warszawa 1988.

Kuryłowicz M.: Prawo rzymskie. Historia - tradycja - współczesność. Lublin 2003.

Kuryłowicz M.: Słownik terminów, zwrotów i sentencji prawniczych łacińskich oraz pochodzenia łacińskiego. Kraków 2002.

Leksykon tradycji prawa prywatnego. Pojęcia podstawowe. Red. A. Dębiński, M. Jońca. Warszawa 2016.

Litewski W.: Rzymskie prawo prywatne. Warszawa 1994.

Micelli M.: Studi sulla „rappresentanza” nel diritto romano. Milano 2008.

Micelli M.: Studi sulla struttura formulare delle actiones adiecticiae qualitatis. Torino 2001.

Miskić M.: Actiones adiecticiae qualitatis: Master's liability based on praepositio and iussum. „Ius Romanum” 2017, nr 2.

Pilloni S.: La posizione del terzo nel diritto delle obbligazioni, 2014, https://iris.unipa. it/retrieve/handle/10447/109068/153805/La posizione del terzo nel diritto delle obbligazioni. Tesi di Dottorato Dott.ssa Sara Pilloni.pdf [dostęp: 1.03.2019].

Prawo rzymskie. Słownik encyklopedyczny. Red. W. Wołodkiewicz. Warszawa 1986. Savigny F.K.: Das Recht des Besitzes. Eine civilistische Abhandlung. Giessen 1837.

Simshäuser W.: Papinians Beitrag einer Rechtsscheinhaftung im klassischen römischen Recht. In: Iuris vincula. Studi in onore di Mario Talamanca. Vol. 7. Napoli 2001.

Schlösser B.: Die Bedeutung der praepositio für den Handelsverkehr im antiken Rom. Berlin 2008.

Sobczyk M.: Condictio causa data causa non secuta and development of the contractual system. „Krakowskie Studia z Historii Państwa i Prawa” 2018, T. 11, z. 2.

Van der Bergh R.: He's One Who Minds the Boss's Business. „Fundamina” 2015, z. $21 / 2$.

Vandolini M.: Actiones adiecticiae qualitatis: categoria dogmatica o nomen iuris? Macerata 2008.

Wacke A.: Von der Reeder- und der Betriebsklage zur direkten Stellvetretung. „Zeitschrift der Savigny-Stiftung für Rechtsgeschichte, Romanistiche Abteilung“ 1994, Nr. 111.

Wang Y.: Actiones adiecticiae qualitatis. Responsabilità del pater familias per l'attività dei servi o fili o sottoposti. Roma 2009.

Wesenberg G.: Verträge zugunsten Dritten. Rechtsgeschichtliches und Rechtsvergleichendes. Weimar 1949.

Wielka encyklopedia prawa. T. 1: Prawa świata antycznego. Red. B. Sitek, W. Wołodkiewicz. Warszawa 2014.

Zimmermann R.: The Law of Obligations. Roman Foundations of the Civilian Tradition. Cape Town-Wetton-Johannesburg 1990.

Żeber I.: Jeszcze o institorze i o actio institoria. „Acta Universitatis Wratislaviensis”. Prawo CCCX 2009. 
Marek Sobczyk

\section{Zum Prinzip alteri stipulari nemo potest im römischen Recht}

Schlüsselwörter: Vertrag zugunsten eines Dritten, direkte Vertretung, alteri stipulari nemo potest, actiones adiecticiae qualitatis

Zusammenfassung: Der Artikel befasst sich mit dem Problem der Umsetzung des römischen Prinzips alteri stipulari nemo potest, laut dem es verboten war, Verträge zugunsten eines Dritten abzuschließen und andere direkt zu vertreten. Es wurde aufgezeigt, wie dieses Prinzip verstanden und hinsichtlich der Anforderungen des Stipulationskontraktes und der den römischen Formularprozess bestimmenden Regeln begründet wird. Umrissen wurden auch Ausnahmen von dieser Regel, die den Vorbehalt einer Leistung an einen Dritten im Falle eines anfechtbaren Interesses der Vertragspartei und des Vorbehalts einer Vertragsstrafe ermöglichen. Umfassender erörtert wurde auch die Frage des Abschlusses von Verträgen durch Untergebene (Sklaven, Kinder, die der väterlichen Gewalt unterliegen) mit der Auswirkung auf ihren Vorgesetzten und der Verantwortung ihres Vorgesetzten.

Marek Sobczyk

\section{The alteri stipulari nemo potest principle in Roman law}

Keywords: third party contract, direct representation, alteri stipulari nemo potest, actiones adiecticiae qualitatis

Summary: The article deals with the problem of the application of the Roman principle alteri stipulari nemo potest, which expresses the prohibition of the conclusion of contracts in favour of a third party and direct representation. It shows the understanding of this principle and its justification in relation to the requirements of the contract of stipulation and the principles governing the Roman formula process. Exceptions to this principle have also been outlined, allowing the reservation of the benefit to a third party in the event of the existence of a contestable interest of a party to the contract and the reservation of a contractual penalty. The issue of concluding contracts by subordinates (slaves, children subject to paternal authority) with effect on their superior and the responsibility of the superior has been discussed in more detail. 